Vol. 13 - August 2013

Print ISSN 2012-3981 • Online ISSN 2244-0445

doi: http://dx.doi.org/10.7719/jpair.v13i1.219
JPAIR Multidisciplinary Research is produced by PAIR, an ISO 9001:2008 QMS certified by AJA Registrars, Inc.

\title{
Legal Perspective on Civil Remedies in the Malaysian Securities Industry
}

\author{
ASMAH LAILI HJ YEON \\ ORCID No.: 0000-0002-3159-6973 \\ asmah485@uum.edu.my \\ College of Law, Government and International Studies \\ Universiti Utara Malaysia, Malaysia
}

\begin{abstract}
Malaysia's capital market has performed well in 2009 and this is reflected from the Malaysia's biggest rise of capital in the form of Maxis Bhd's RM11.2 billion of initial public offering in 2009. Nevertheless, self-interests may create behaviors that pose risks to the safety of investors and the integrity of markets. Therefore, the Malaysian Securities Commission (SC) implemented a civil action against the offender of securities crimes in order to protect investors and to cover losses faced by investors because of securities crimes. The objective of this paper is to discuss and analyze the law and enforcement of civil action in securities industry in Malaysia. This is a legal research and involved examining legal data such as statutes and court cases. The Capital Markets and Services Act 2007(CMSA 2007) regulate matters relating to the activities, markets and intermediaries in the capital markets. The CMSA 2007 provides provisions relating to civil remedies to the victims of securities crimes and further empowers the SC to enforce administrative and civil actions. The analysis on enforcement of civil actions of SC shows that the outcome of the said strategy is very encouraging and accepted well by the industry player.
\end{abstract}

Keywords - securities law, civil action, legal research, Malaysia 


\section{INTRODUCTION}

In the global scenario, the last two decades have marked the notable ascent of capital markets in the functioning of the global economy. In 1990, global equity market capitalization amounted to only USD10.4 trillion and was less than half the size of the world economy (IOSCO, 2009). At its peak in 2007, global equity market capitalisation had risen six-fold to USD64.6 trillion, about 1.17 times nominal global GDP. Malaysia's capital market has performed well in 2009 despite the lingering effects of the global financial crisis and ensuing economic downturn. This is reflected from the Malaysia's biggest capital-raising exercise ever, in the form of Maxis Bhd's RM11.2 billion initial public offering in 2009 (Maxis Annual Report, 2010)

The Securities Commission (SC) is the main regulator of securities and futures markets in Malaysia and has been entrusted to several functions under the Securities Commission Act 1993 (SCA 1993). Among others, the SC is to advise the Minister and regulate on all matters relating to securities and derivatives market; ensure provisions of securities law are complied with; regulate the take-over and merger of companies and matters relating to unit trust schemes and others.

Under the Capital Markets and Services Act 2007 (CMSA 2007), there are two ways on how investors of securities markets been protected under the law. The traditional way is using criminal sanction against the securities crimes offenders and civil sanction is another method used by the SC to provide remedies to the victim of the crime. Hence, the objective of this paper is to discuss and analyze the law and enforcement of civil action in securities industry in Malaysia.

Section 199 to 201 of CMSA 2007 provides provisions relating to civil remedies to the victims of securities, crimes and further, section 354 to 361 of the CMSA 2007 give power to the Securities Commission to enforce administrative and civil actions.

\section{Securities Markets Crimes under the CMSA 2007}

Before the writer goes further to discuss on the issue of civil action by the SC, it is vital to clarify some matters in relation to the securities crimes. According to CMSA 2007, there are eight main types of market misconduct or prohibited conduct in securities market i.e. false trading (s. 175(1)), market rigging transactions (s. 175(2)), stock market manipulation (s. 176), false or misleading statements (s. 177), fraudulently inducing persons to deal in securities (s. 178), use of manipulative and deceptive devices (s. 179), dissemination of information about illegal transactions (s. 181) and insider trading (s. 188). The conventional way on how to combat these crimes is by using the strategy of criminal sanctions where under section 182 a person 
who contravenes section $175,176,177,178,181$ or 188 commits an offence and on conviction the offender could be imprisonment for a term not exceeding ten years and fined of not less than one million ringgit.

Research findings by Asmah and Faridahwati (2011) showed that offenders of securities crimes in Malaysia are a company's insider such as director, finance officer, executive officer and company's staffs. The typical offences committed include false statement, misappropriation of company's assets, fraudulent act in the sale and purchase of securities and others. Further, according to the finding of the research shows that in 2009, the SC successfully bring 16 cases to the Court of Justice, and in the year of 2008 only 12 cases, 11 cases in 2007, 9 cases in 2006 and 11 cases in 2005. Criminal sanction is the conventional way used by most of the regulators in the global markets to combat white collar crime especially in securities markets. Simultaneously, regulators adopted the civil action strategy to compensate victims of securities industry as to create greater investors' confidence to the markets. The strength of securities market is based on investor confidence and market integrity.

\section{Civil Action by the Securities Commission under the CMSA 2007}

The duties of SC are to seek and promote confidence in the integrity of securities market. Investors must be assured they are protected from misleading, manipulative or fraudulent practices. They want to have recourse to justice and know that wrongdoers will be held accountable.

Section 200 of CMSA 2007 empower the SC to institute civil proceedings in court against the offender of securities crimes whether or not that person has been charged with the offence or whether or not a contravention has been proved in a prosecution. If the SC considers that it is in the public interest to do so the SC will institute civil action against the offender in order to (a) recover an amount which should not exceed three times the gross amount of pecuniary gain made or loss avoided by the criminal; and (b) claim penalty in such amount as the court considers appropriate having regard to the severity or gravity of the offence being the amount not exceeding one million ringgit.

Further, in insider trading offences the SC may institute civil action if it considers that it is in the public interest to do so against or any other person involved in the contravention to (a) recover an amount equal to three times the amount being the difference between the price at which the securities were acquired/disposed, or agreed to acquired/disposed by the insider or the other person, and the price at which they would have been likely to have been acquired/disposed at the time of the acquisition/ disposal or agreement, if the information had been generally available; and (b) claim 
civil penalty in such amount as the court considers appropriate having regard to the seriousness of the contravention, being an amount not more than one million ringgit. ${ }^{1}$

The effectiveness of the strategy can be witnessed in the Swisscash case. The landmark settlement of RM30 million in relations to the Swisscash investment scam was a major achievement in this regard. ${ }^{2}$ This is by far the largest settlement in the history of Malaysia's capital market and the money will be used to compensate victims of the scam. Further in another case, the SC took an action against a company director following civil enforcement by SC, the High Court ordered Kenneth Vun, the former managing director and shareholder of FTEC Resources Bhd, to repay the company RM2.4 million of IPO proceeds that he used for his personal benefit. ${ }^{3}$

In the other scenario, on 29 March 2011 the SC entered into a settlement with Mr Heah Sieu Lay in the sum of RM77,576 when he agreed, without admission of liability to make the payment. This sum constituted a disgorgement of twice the profits arising from alleged irregularities in his trading of Nexnews Berhad shares between 4 May 2007 and 10 May 2007. This settlement followed the SC's proposed proceedings under section $89 \mathrm{E}$ and 90(1) of the Securities Industry Act $1983 .{ }^{4}$

On 29 March 2011 the SC entered into a settlement with Mr Tan Kong Han in the sum of RM24,760 when he agreed, without admission of liability to make the payment. This sum constituted a disgorgement of twice the profits arising from alleged irregularities in his trading of Nexnews Berhad shares between 3 May 2007 and 17 August 2007. This settlement followed the SC's proposed proceedings under section 89E and 90(1) of the Securities Industry Act 1983.

The SC also entered into a settlement on 22 March 2011 with Kanesan a/l Veluppillai in the sum of RM98,247 when he agreed, without admission of liability to make the payment. This sum constituted a disgorgement of three times the profits arising from alleged irregularities in his trading of Nexnews Berhad shares between 3 May 2007 and 10 May 2007. This settlement followed the SC's proposed proceedings under section 89E and 90(1) of the Securities Industry Act $1983 .{ }^{6}$

1 Refer to section 201(5) and (6) of the CMSA 2007

2 Zarinah Anwar (2009). "Sustaining confidence and trust in our capital market". The Edge Weekly, 28

December 2009. Also can be found at http://www.sc.com.my/main.asp?pageid=371\&menuid

3 SC Enforcement : Civil action 2011 at http://www.sc.com.my/

4 SC Enforcement : Civil action 2011 at http://www.sc.com.my/

5 SC Enforcement : Civil action 2011 at http://www.sc.com.my/

6 SC Enforcement : Civil action 2011 at http://www.sc.com.my/ 


\section{FRAMEWORK}

Looking at the above cases, it is important to note that an amount recovered by the SC in an action under section 200 of CMSA 2007 should be applied in the following manner. Firstly, the amount is to reimburse the SC for all costs of the investigation and proceedings. Secondly, to compensate persons who have suffered loss or damage as a result of the offence. If the SC considers it is not practicable to compensate the victim because of the difficulty of ascertaining or notifying the victim, the amount obtain will be paid to the capital markets compensation fund (CMCF) or retain by the SC to defray the costs of regulating the capital market with the approval of the Minister. The civil proceedings can commenced at any time within twelve years from (a) the date on which the cause of action accrued or (b) the date on which the Commission or the person who instituted the proceedings.

The CMCF as mentioned above is managed and administered by the Corporation. ${ }^{7}$ The Corporation have all powers in performing its functions including a) establish processes and procedures which are fair, reasonable and transparent to determine claims for compensation; (b) pay out compensation; (c) petition the winding up of a relevant person; (d) determine the financial and operational condition of a relevant person and the likelihood of the relevant person triggering an event of default; (e) determine, charge, collect and receive contributions, levies, fees and other payments from relevant persons or claimants and expend the same in furtherance of all or any of the functions of the Corporation; (f) take any action in respect of its function in managing and administering the CMCF.

The CMCF consist of the following sources (a) monies provided to the Capital Market Compensation Fund by the Commission; (b) monies provided to the Capital Market Compensation Fund by the relevant stock exchange and derivatives exchange; (c) contributions made by the Capital Market Development Fund; (d) contributions made by a relevant person as provided for under section 160; (e) interest and profits accruing from time to time from the investment of the Capital Market Compensation Fund; (f) any sum of money borrowed by the Corporation pursuant to subsection 142(2); (g) monies recovered by or on behalf of the Corporation in the exercise of a right of action conferred under this Part; (h) monies paid by an insurer under a contract of insurance or indemnity entered into by the Corporation under section 170 of this Part; and (i) all other monies lawfully paid into the Capital Market Compensation Fund pursuant to this Act or any other guidelines issued by the Commission (section 159, CMSA 2007). The Corporation is empowered to credit all direct operating income to the fund, and charge against the Fund, all

7 Section 142(1) of CMSA 2007. 
expenses and costs incurred by the Corporation in managing the Fund.

Before the amendment of CMSA 2007 in the year of 2011, the payments out of compensation fund (previously, Bursa Malaysia is the administrator of the fund) can be used for (a) the amount of all claims, including costs, allowed by the relevant stock exchange; (b) all legal and other expenses incurred in investigating or defending claims made to CF; (c) all premiums payable in respect of contracts of insurance or indemnity entered into by the relevant stock exchange; (d) all expenses incurred in the administration of the CF including remuneration and allowances of any persons employed by the relevant stock exchange; and (e) all other monies payable out of the CF in accordance to the law. ${ }^{8}$

In addition, this fund also can be used for compensating the person suffering the monetary loss at any particular time because of (a) a defalcation or because of fraudulent misuse of monies or other property, by a director, officer, employee or representative of a holder of a Capital Markets Services License who carries on the business of dealing in securities that is at that time a participating organizations or (b) an insolvency of participating organization. ' After the amendment in 2011, the Corporation is assigned with the tasks to make rules to be approved by the SC governing the proper administration of the Corporation and the CMCF. The rules include among others the scope and category of claimants who are eligible to make claim from the CMCF, the manner in which claims are to be made; the manner in which claims are to be determined and awarded by the Corporation and others. ${ }^{10}$

\section{Recovery of Loss or Damages by Victim}

The CMSA 2007 also gives rights to victims of securities crimes to claim damages. Section 199 and 201 states that a person who suffers loss or damages by reason of or by relying on the conduct of another person who has committed securities offences, may recover the amount of loss or damages by instituting civil proceedings against the other person, whether or not the other person has been charged with an offence in respect of the crime. Loss and damages includes an unrealized loss or gain, in the price or value of securities of a corporation being the difference between (a) the price or value of securities in a transaction in connection with which the person claims to have suffered loss or damages, and (b) the price which would have been the likely price of the securities in the transaction, or the value which it is likely that such securities would have had at the time of that transaction, if the contravention had 
not occurred.

In the case of insider trading, section 201(3) provides that where an insider acquired/disposed or agreed to acquire/dispose or procured another person to acquire/dispose or agree to acquire/dispose securities from a person (bonafide seller/ buyer) who did not possess the information, the seller or buyer may by civil action against the insider or any other person involved in the act, recover, as loss or damages suffered by the buyer, the difference between (a) the price at which the securities were acquired/disposed and (b) the price at which the securities would have been likely to have been acquired/disposed at the time of the acquisition/disposal or agreement if the information had been generally available.

\section{Administrative and Civil Actions under CMSA 2007}

Under section 354 of the CMSA 2007, the SC can take action against any person who contravenes provisions in the CMSA or fails to comply with, observe, enforce or give effect to (i) the rules of a stock exchange, approved clearing house or central depository; (ii) any written notice, guidelines issued or condition imposed by the SC; or (iii) any rule of a recognized self-regulatory organization. A person here includes an exchange holding company, a stock exchange, a central depository, an approved clearing house, a participant, a participating organization, a depository participant and others as stated in section 354 (2) of the CMSA 2007.

If any of the persons has committed a breach and the SC is satisfied that it is appropriate to take action against that person, the SC may take any or more of the following actions: (a) direct the person in breach to comply with, observe, enforce or give effect to such rules, provisions, written notice, condition or guideline; (b) impose a penalty in proportion to the severity or gravity of the to any other person in breach but in any event not exceeding five hundred thousand ringgit; (c) reprimand the person in breach; (d) require the person in to take such steps as the SC may direct to remedy the breach or to mitigate the effect of such breach including making restitution to any other person aggrieved by such breach; (e) in the case of a breach of provisions in CMSA or guidelines issued, the SC can refuse to accept or consider any submission relating to the above matter; (f) in the case of a promoter or a director of a corporation, in addition to the actions that may be taken under item (a) to (e) as above, the actions may be taken by the SC are (1) impose a moratorium on, or prohibit any trading of or any dealing in the corporation's securities or in any other securities which the SC thinks fit by the promoter or director; (2) issue a public statement to the effect that in the SC's opinion, the retention of the office by the director is prejudicial to the public interest. 
It is interesting to note that the CMSA 2007 provides several methods to safeguard the industry securities transactions. The questions now are whether these strategies being implemented by the regulator or not is another issue to consider and to what extent is the responsibility of market's participants themselves to uphold law and regulations also. If every participant is a law abiding person, of course there is no need for the regulator to introduce different types of strategy to combat unethical and illegal conduct in the securities market.

In relation to action in paragraph (d) as above, the SC in determining whether or not restitution is to be made by a person in breach will based on the criteria: (a) the profits that have accrued to such person in breach; or (b) whether one or more persons have suffered loss or been otherwise adversely affected as a result of the breach. Section 354 (8) provides the SC may sue a person who fails to pay penalty (paragraph (b)) as a civil debt due to the Government of Malaysia and further under subsection (9) mentioned about the SC may sue a person who fails to pay restitution (paragraph (d)) for a civil debt due to the persons aggrieved by the breach. This strategy is not only to serve as a punishment to the offender but also give protection to the victims of unethical conducts in securities markets.

Section 356 of the CMSA 2007 authorizes the SC to take action against the licensed person who is in breach of any securities laws, written notice, guidelines, any condition or restriction granted under the CMSA 2007. The SC also can take action against licensed holder who jeopardize the interests of clients of the licensed person or be prejudicial to the public interests. Type of actions taken by the SC is similar to section 354 above.

\section{OBJECTIVES OF THE STUDY}

The objective of this paper is to examine and discuss the civil remedy strategies in the Malaysian Securities Industry Law.

\section{METHODOLOGY}

This is a qualitative legal research paper. According to Mahdi Zahraa (1998) a legal research is a fresh, diligent, systematic, inquiry or investigation of the factual data and/or theoretical concepts of the rules and principles of a particular legal issue in an attempt to discover, revise or improve the relevant concepts, theories, principles and applications. The source of legal data is from primary and secondary sources. The researcher analyses provisions of statutes, court cases, articles, books and tertiary data which are relevant to the research paper. The scope of discussion is based on the 
Capital Markets and Services Act 2007. The researcher also examines selected cases in relation to civil remedy in the capital markets. The data were analyzed using an analytical and critical analysis (Walker, 1980) and in addition, content analysis were used by applying judicial interpretation method which includes literal rule, golden rule, mischief rule and purposive rule especially in regards to primary data.

\section{DISCUSSION}

The writer elaborates on selected cases involving action taken under section 356. In 2010, the SC has taken action against Mayban Investment Management Sdn. Bhd. (a Capital Markets Services Licence holder carrying out dealing in securities and fund management) because of breach of Section 356(1) of the Capital Markets and Services Act 2007 ("CMSA"). The brief description of the misconduct are (a) failure to comply with several requirements of the CMSA, the Guidelines on Compliance Function for Fund Managers ("Compliance Guidelines") including having adequate measures to safeguard clients' assets, and policies and procedures to address conflicts of interest situations; and (b) Board of Directors' failure to put in place adequate internal controls and policies and procedures to ensure compliance with all laws, regulations, guidelines and code of conduct. The company has to pay penalty of RM100,000.

In 2011, the case of Hwang DBS Investment Bank Berhad ("HDBSIB") ${ }^{11}$ (a Capital Markets Services Licence holder carrying out dealing in securities and advising on corporate finance) has breach of Section 356 of the Capital Markets and Services Act 2007 for failure to comply with the Securities Commission's Guidelines on Prevention of Money Laundering and Terrorism Financing For Capital Market Intermediaries ("AML Guidelines") and Guidelines on Market Conduct and Business Practices for Stockbrokers and Licensed Representatives ("Market Conduct Guidelines"). Description of misconduct includes (a) failure to identify and report suspicious transactions; (b) failure to take reasonable steps to minimise HDBSIB exposure to money laundering risk; and (c) failure to conduct enhanced Customer Due Diligence ("CDD") on 'high risk' clients. The action taken against the company are (1) reprimand; (2) penalty of RM250,000; and (3) directive to develop and implement a comprehensive Anti-Money Laundering training programme for its staff.

Besides the provisions, section 357 imposes civil liability to the person in contravention of the securities laws where a person who suffers loss or damages by relying on the conduct of another person who has contravened any securities

11 SC Enforcement : Civil action 2011 at http://www.sc.com.my/ 
regulations may recover the amount of the loss or damage by instituting civil proceedings. The SC also may recover loss or damage for the purpose of public interests by instituting civil proceedings against the person who has contravened any securities regulations whether or not the person has been charged with an offence or not. The limitation period for such action may be begun at any time within six years from the date on which the cause of action accrued or the date on which the victim became aware of the contravention whichever is the later. ${ }^{12}$

The strategy taken by the Government of Malaysia to include civil sanction as part of the method to protect investors' interest is admittedly an effective tool and an investor's friendly strategy. The regulation model was adopted from the United States and it becomes one of the alternatives strategy used by the SC to combat securities crimes in Malaysia. The SC has yet to use aggressively the civil sanctions strategy compared to criminal sanctions. This can be evidenced from the statistic published by the SC in 2008 to 2011 (up to the month of April 2011), only 13 civil action cases compared to criminal prosecution which involved more than 70 cases. But looking at the statistics on civil actions taken by the SC, the trend now becomes more positive where in 2008 and 2009 only 1 case per year but in 2009 it goes up to 7 cases and 2011 (in 4 months period) 5 cases already taken action by the SC.

Further, in the case of administrative actions, evidence shows that action in paragraph (d) of sections 354 and 356 of the CMSA is not taken at all by the SC. In the period of 2008 to 2011, there are 32 cases involving in administrative action taken by the SC but restitution is not one of the actions adopted by the SC against the person in breach. Most of these cases involved payment of penalty, reprimand and suspension or revocation of license. The writer is of the view that the SC should take more effort to materialize whatever strategy provided by the law especially if it is to give benefits to the investors. If investors have confidence in the market then it will boost the Malaysian economy.

\section{CONCLUSION}

As a conclusion, we may say that over the past year, the SC has focused its efforts on promoting confidence and trust in Malaysia's capital market, and on helping the market to function efficiently, providing lower financing cost while remaining resilient.

12 section 358 of the CMSA 2007 


\section{RECOMMENDATION}

Therefore, there is a need to review corporate governance issues including institutions that have regulatory duties, intermediaries and professionals that have fiduciary obligations to put their customers' interests ahead of their own, market venues that need to maintain a transparent, fair and orderly trading environment and boards of directors who need to exercise greater stewardship and ensure a fair deal for all their stakeholders.

In this regard, there is still a sense that the private sector has not really absorbed the value of ethical conduct and responsibility to other stakeholders. Preventing a recurrence of a financial crisis requires not only reforms to financial regulation but more importantly, a change in the mindset of market participants. It is important that all participants of the industry work together to achieve positive changes in the attitudes of all stakeholders in line with public expectations.

\section{LITERATURE CITED}

Asmah L. \& Faridahwati

2011 Pelaksanaan kerangka perundangan penzahiran dalam pasaran industri sekuriti di kalangan pemegang-pemegang lesen di Malaysia. Laporan Akhir yang dibiayai oleh FRGS, Kementerian Pengajian Tinggi Malaysia 2011.

ILBS

2011 The Capital Markets and Services Act 2007 (Act 671). Kuala Lumpur: ILBS.

ILBS.

2010 The Securities Commission Act 1993 (Act 498). Kuala Lumpur: ILBS.

IOSCO

2009 The Annual Report. Refer to the website of sc.com.my

Zarinah A. \& Kar M.T.

2003 "Building a framework for corporate transparency: challenges for global capital markets and the Malaysian Experience". International Accountant, Issue 18, February 2003.

Zarinah A.

2009 "Sustaining confidence and trust in our capital market". The Edge Weekly, 
28 December 2009. Also can be found at http://www.sc.com.my/main. asp?pageid $=371 \&$ menuid

Mahdi Z.

1998. Research Methods for postgraduate Overseas students, Glasgow: Univision Press pp 17.

Maxis

2010 Maxis Annual Report 2010. Kuala Lumpur.

SC Enforcement : Civil action 2010 at http://www.sc.com.my/

SC Enforcement : Civil action 2011 at http://www.sc.com.my/

Shanti, G.

2010 Capital Market Laws of Malaysia. Selangor: Lexis Nexis.

Shanty R., Oasco, J. \& Anil, J.

2010 Concise Principles of Company Law in Malaysia (2 $2^{\text {nd }}$ ed.). Selangor: Lexis Nexis.

Sharif A.S., Singh, A., Ahmad, R. \& Jalal, J.

2009 Strenghthening Governance in Asia-Pasific. Myths, Realities and Paradoxes. India: MacMillan Publishers.

Malloy, F. T.

2003 "Regulation, Compliance and the Firm". 76 TEMP.L.REV. 451.

Malloy, F. T.

2005 "Corporate decision making: Disclosure stories". 32 Fla.St.U.L. Rev.617. Florida State University Law Review.Florida State University Law Review. Winter, 2005.

Mahmood, N. R.

2005 "Managing Corporate Responsibility and Crisis through Fairness, Transparency and Accountability". Ucapan disampaikan dalam Asia Corporate Governance Conference 2005, Kuala Lumpur. 
Reed, S., Storehead \& Corley

2005 The Legal \& Regulatory Environment of Business (13th ed.). New York: McGraw-Hill.

Walker, D.

1980 The Oxford Companion Law. Oxford: Clarendon Press pp 837.

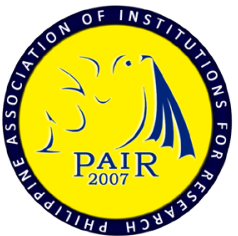

Pursuant to the international character of this publication, the journal is indexed/aggregated by the following agencies: 1) Public Knowledge Project, a consortium of Simon Fraser University Library, the School of Education of Stanford University, and the British Columbia University, Canada; 2) Philippine E-Journals; 3) Google Scholar; 4) Index Copernicus; 5) Scholastica; 6) Researchgate; 7) Lacriee of France; 8)University Library of Leipzig, Germany; 9) Linguist List; and 10) The JournalTOCs. 